July 2020

\title{
Is Incorporation the Solution to the Enigma of Corporate Tax Residency for International Tax Purposes?
}

Charles Edward Andrew Lincoln IV

charlieealincolniv@yahoo.com

Follow this and additional works at: https://scholarship.law.tamu.edu/lawreview

Part of the Business Organizations Law Commons, and the Tax Law Commons

\section{Recommended Citation}

Charles E. Lincoln IV, Is Incorporation the Solution to the Enigma of Corporate Tax Residency for International Tax Purposes?, 7 Tex. A\&M L. Rev. Arguendo 35 (2020).

Available at: https://doi.org/10.37419/LR.V7.Arg.3

This Arguendo (Online) is brought to you for free and open access by Texas A\&M Law Scholarship. It has been accepted for inclusion in Texas A\&M Law Review by an authorized editor of Texas A\&M Law Scholarship. For more information, please contact aretteen@law.tamu.edu. 


\title{
IS INCORPORATION THE SOLUTION TO THE ENIGMA OF CORPORATE TAX RESIDENCY FOR INTERNATIONAL TAX PURPOSES?
}

\author{
Charles Edward Andrew Lincoln IV
}

I. INTRODUCTION

TABLE OF CONTENTS

II. THE CONCEPT OF RESIDENCY INTERTWINED WITH INCORPORATION AND DIFFERENT TYPES OF RESIDENCY

A. What, then, is Incorporation?

B. Different Types of Tests for Residency

III. WHY INCORPORATION IS A BETTER SOLUTION

IV. Musgrave's ECONOMiC ANALysis In RELATION tO CAPITAL EXPORT AND CAPITAL IMPORT NEUTRALITY

V. Further Thoughts: Distinction Between a Legal Formalistic and Legal REALISTIC PERSPECTIVE ON CORPORATE TAX RESIDENCY

VI. CONCLUSION

\footnotetext{
${ }^{*}$ Charles Edward Andrew Lincoln IV, received his LL.M. in Tax Law from Boston University in May 2018; his Advanced LL.M. in International Tax Law from the University of Amsterdam in October 2017; and, his J.D. from Texas A\&M University in May 2016 after graduating, cum laude, with a Bachelor's Degree in Government from Harvard University, in May 2013. Many heartfelt thanks to Professor William H. Byrnes, IV of Texas A\&M University who has mentored me in tax law and transfer pricing since I was a J.D. student at Texas A\&M.

DOI: https://doi.org/10.37419/LR.V7.Arg.3
} 


\section{INTRODUCTION}

Incorporation of a company for testing residency - if applied uniformly - is likely the best and most accurate way to reflect corporate residency for tax purposes. However, it does not always reflect economic reality. There is not a consensus on what the best approach is. The Organization for Economic Cooperation and Development (“OECD”) countries overwhelmingly use three tests for residency: incorporation, ${ }^{1}$ central management and control, ${ }^{2}$ and domicile. ${ }^{3}$ Indeed, a court in the United States or other jurisdictions may often ask if tax-avoidance motives exist when incorporation occurs in one jurisdiction and central management and control occurs in another. ${ }^{4}$

This Article follows the 2017 Tax Cuts and Jobs Act on many international tax provisions that caused a shift in thinking at both the U.S. level, and at the international level in terms of deciding what formulations would be the best way to ensure proper taxation while promoting horizontal and vertical equity.

The genesis of this Article is a response and critique of an article on the same subject by the same author: Charles Edward Andrew Lincoln IV, Is Incorporation Really Better Than Central Management and Control for Testing Corporate Residency? An Answer to Corporate Tax Evasion and Inversion, 43 OHIO N.U. L. REV. 359 (2017). The author now critiques the point of that article and comes to a different conclusion based on different criteria: specifically, new case law, Musgrave's economic theory of accretion of wealth, and the importance of substance-over-form doctrines.

\section{THE CONCEPT OF RESIDENCY INTERTWINED WITH INCORPORATION AND DIFFERENT TYPES OF RESIDENCY}

\section{A. What, then, is Incorporation?}

Incorporation is a legal principle as much as it is a social, philosophical, and anthropological principle. It represents the confluence of English common law emanating from Anglo-Saxon England to Enlightenment Europe of unified entities having a corporeal body. From a modern legal perspective, incorporation is the formation of a legal entity that is separate from a

\footnotetext{
${ }^{1}$ See Eric J. Smith, The U.S.-Mexico Tax Treaty, 8 Fla. J. INT'L L. 97, 105 (1993).

${ }^{2}$ Luca Cerioni, The "Place of Effective Management" as a Connecting Factor for Companies' Tax Residence Within the EU vs. the Freedom of Establishment: The Need for a Rethinking?, 13 GERMAN L.J. 1095, 1095-96

${ }^{3}$ See Topsnik v. Comm'r of Internal Revenue Serv., No. 15-1251, 2017 WL 9939283 (D.C. Cir. Nov. 14, 2017).

${ }^{4}$ There are many cases dealing with substance-over-form issues. See Starr Int'l Co. v. United States, 275 F. Supp. 3d 228, 238 (D.D.C. 2017) ("The letter explained that, under the circumstances, the Competent Authority could not 'conclude that obtaining treaty benefits was not at least one of the principal purposes for moving Starr's management, and therefore its residency, to Switzerland.' . . . In support of that conclusion, the letter highlighted the following four considerations: [Starr]'s original incorporation in Panama and its management and control in Bermuda suggest the original corporate structure may have been developed with tax avoidance purposes in mind and/or with a purpose of avoiding the provision of information on [Starr]'s activities to the Internal Revenue Service.”).
} (2012). 
person..$^{5}$

Justice Marshall- one of the most prolific Chief Justices of the United States Supreme Court-somewhat famously provided that "[a] corporation is an artificial being, invisible, intangible, and existing only in contemplation of law. Being the mere creature of law, it possesses only those properties which the charter of its creation confers upon it, either expressly, or as incidental to its very existence. These are such as are supposed best calculated to effect the object for which it was created." 6 The Fletcher Cyclopedia of the Law of Corporation defines the corporation "as an entity (usually a business) having authority under law to act as a single person distinct from the shareholders who own it and having rights to issue stock and exist indefinitely," but also defines it as "a group or succession of persons established in accordance with legal rules into a legal or juristic person that has legal personality distinct from the natural persons who make it up, exists indefinitely apart from them, and has the legal powers that its constitution gives it."7

Interestingly, at least by Classical antiquity and certainly by the time of the Roman Republic, "[t]here is authority for the statement that the concept of collective entity antedates that of the individual; that 'groups of men united by the reality of fiction of blood relationship' into families, clans or tribes were recognized units of primitive society even before the individual was so regarded." 8 Regardless of the specific history and purposes, "[i]t is well settled . . . that a

${ }^{5}$ Incorporation, BLACK'S LAW DiCTIONARY (11th ed. 2019).

${ }^{6}$ Trs. of Dartmouth Coll. v. Woodward, 17 U.S. 518, 636 (1819).

${ }^{7}$ Corporation, BLACK'S LAW DictionaRY (11th ed. 2019).

${ }^{8} 1$ Fletcher Cyclopedia Corp. $§ 1$ n.1 (2019) (quoting MaIne, AnCIEnT Law (4th ed.)). See also In re Steinberg's Estate, 274 N.Y.S. 914, 919 (Sur. Ct. 1934). "For a history of the earliest English trading companies, beginning in 1359 with the Merchant Adventurers of England (The Hamburg Company later), the Eastland Company (1579), the Levant Company (1581), see 3 Encyc. Laws of England, tit. Companies, Chartered 239. The East Indian Company, chartered December 31, 1600, introduced (1612) the joint stock feature into trading companies. See history of its growth and charters in 3 Encyc. Laws of England, tit. Companies, Chartered 243." 1 Fletcher Cyclopedia Corp. § 1 n.3 (2019).

Anthropologically speaking, it is unclear whether individual identity must precede group identity historically or whether the opposite is true. Arguably empirical evidence exists on both sides of the question. The full quote from Henry Maine's account of Ancient Law seems to indicate some ambivalence by the time of the Roman Republic whether the individual preceded the group, but seems more convinced that the group defined the individual first:

"In order to solve this apparent paradox, and to bring into greater clearness the train of ideas which I have been endeavouring to indicate, I must borrow the results of the inquiry which was attempted in the earlier portion of the preceding chapter. We saw one peculiarity invariably distinguishing the infancy of society. Men are regarded and treated, not as individuals, but always as members of a particular group. Everybody is first a citizen, and then, as a citizen, he is a member of his order - of an aristocracy or a democracy, of an order of patricians or plebeians; or, in those societies which an unhappy fate has afflicted with a special perversion in their course of development, of a caste. Next, he is a member of a gens, house, or clan; and lastly, he is a member of his family. This last was the narrowest and most personal relation in which he stood; nor, paradoxical as it may seem, was he ever regarded as himself, as a distinct individual. His individuality was swallowed up in his family. I repeat the definition of a primitive society given before. It has for its units, not individuals, but groups of men united by the reality or the fiction of blood-relationship." MAINE, ANCIENT LAW 107-08 (4th ed.).

However, Immanuel Kant laid out an argument in his discussion of antimonies and transcendental thought in the Critique of Pure Reason that there can be no ascertaining one way or another of one side being correct or not in such investigations. He states in resolution to his argument that "there is no possibility of ever ascertaining which side is in the right." Immanuel Kant, Critique of Pure Reason Section VII 513 (Werner S. Pluhar trans., Hackett 
corporation is a distinct legal entity that can act only through its agents." 9

\section{B. Different Types of Tests for Residency}

Incorporation has been defined variously. However, specifically in relation to the tax treaty between the United States and Mexico, "[a]side from one exception . . . the Treaty only applies to persons who are residents of either the United States or Mexico." ${ }^{10}$ Indeed, it must be noted that "[i]n accordance with the U.N. and OECD Models, Article 4 (Residence) provides that 'resident' means any 'person' who is subject to tax in either Mexico or the United States, under the laws of that country, because of his domicile, residence, place of management, place of incorporation, or any other criterion of a similar nature." 11 Although there is a consensus between the United Nations and the OECD, and although the United States, "unlike any other developed country, asserts worldwide income taxing jurisdiction on the basis of citizenship, the Treaty follows the OECD Model, not the U.S. Model, by not including in the definition of 'resident' U.S. taxpayers who have no connection to the United States other than citizenship."12 The matter remains that the "term 'resident' does not include any person who is subject to tax in a contracting country with respect only to income from sources in that country." 13 Indeed, "for example, an individual resident of the United States will be covered by the Treaty since she is subject to U.S. tax because of her residence. By contrast, the Treaty will not cover a U.S. citizen who resides outside of Mexico or the United States." 14

Per what central management and control is, it should be noted that "the "central management and control' test formed the basis of the 'place of effective management' test which, under the Organization for Economic Cooperation and Development (OECD) Model for bilateral conventions against double taxation, is currently adopted as a tiebreaker rule." ${ }^{15}$ A tiebreaker rule is "a criteria for allocating the tax residence of companies in cases where both contracting States consider a company as resident under their own domestic law, and which is also used, as one amongst alternative connecting factors for corporate tax residence."16 In turn, the allocation of corporate tax residence to a country allows the State at issue to tax the company on its worldwide income, thereby representing a factor of utmost importance for the attribution of taxing rights." 17

Alternatively, the concept of domicile is key in taxation. Indeed, for a practical example, the United States Tax Court noted that "with respect to individuals, both the original U.S.-Germany Treaty and the post-2006 treaty limit the definition of a 'resident of a Contracting State' to

Publishing, Co., 1996).

${ }^{9}$ Larsen Chelsey Realty Co. v. Larsen, 656 A.2d 1009, 1024 (Conn. 1995); see also Yale Univ. v. Out of the Box, LLC, 990 A.2d 869, 876 (Conn. App. Ct. 2010).

${ }^{10}$ Smith, supra note 1 , at 105.

${ }^{11} I d$.

${ }^{12} I d$.

${ }^{13} \mathrm{Id}$.

${ }^{14} I d$. (emphasis omitted).

${ }^{15}$ Cerioni, supra note 2, at 1095.

${ }^{16} \mathrm{Id}$. at 1095-96.

${ }^{17} \mathrm{Id}$. at 1096. 
individuals 'liable to tax therein by reason of [domicile or residence]', and both exclude from the definition 'any person who is liable to tax in that State in respect only of income from sources in that State or capital situated therein." 18 The Tax Court went on to state that "the treaty test for residence in a contracting State is the individual's liability to pay tax to the State as a resident, which, in the case of Germany, means that the individual must be taxable on his or her worldwide income." ${ }^{19}$ The Court went on further to state "that [this] is the test for residency under the U.S.Germany Treaty[,] confirmed by the commentary with respect to article 4 of the Organization for Economic Cooperation and Development (OECD) Model Double Tax Convention on Income and Capital (1977) (OECD Model Treaty), article 4, paragraph 1 of which is, in all pertinent respects, identical to article 4, paragraph 1, of the original and post-2006 U.S.-Germany treaties." 20

If dual residency exists, often this dual residency can be resolved through a tiebreaker position in a tax treaty. ${ }^{21}$ Such dual-resident examples can occur in many jurisdictions. ${ }^{22}$ Indeed, it should also be noted that non-resident corporations can have their business profits taxed through permanent establishments. ${ }^{23}$ However, dual residency is a basic form of tax arbitrage, because "the international tax rules of Subpart F (adopted assuming an open system) and the domestic tax rules of residency and entity classification (adopted assuming a closed system), when used together, can result in international tax arbitrage." 24

18 Topsnik v. Comm'r, 143 T.C. 240, 259 (T.C. 2014), aff'd sub nom, Topsnik v. Comm'r of Internal Revenue Serv., No. 15-1251, 2017 WL 9939283 (D.C. Cir. Nov. 14, 2017).

${ }^{19} \mathrm{Id}$. (citations omitted).

${ }^{20}$ Id. at 259-60. "THE COMMENTARY TO Article 4 paragraph 1 states, in pertinent part: 'As far as individuals are concerned, the definition aims at covering the various forms of personal attachment to a State which, in the domestic taxation laws, form the basis of a comprehensive taxation (full liability to tax).' OECD Committee on Fiscal Affairs, Model Tax Convention on Income and on Capital, at C(4-9) (1997)." Id. at 260.

21 "If this situation arises, you must consider whether one rule supersedes the other (that is, whether the company can be said to be resident in only one of the jurisdictions). The answer to this question depends on whether a double tax treaty applies and, if so, whether the treaty provides for the company to be resident in only one jurisdiction." Practical LAw TAX, Companies: UK Residence ANd PERMANENT Establishments, Practice Note 4-204-0101, Westlaw (database updated June 2019).

22 "Because the United States defines corporate tax residence according to place of incorporation, while Ireland uses the location of central management and control, a company incorporated in Ireland with central management and control in the United States is a tax resident of neither country." Tyler H. Lippert, OECD Base Erosion \& Profit Shifting: Action Item 6, 37 Nw. J. INT'L L. \& Bus. 539, 546 (2017).

${ }^{23}$ See PracticAL TAX LAW, supra note 21 ("A non-resident company is generally subject to corporation tax on its profits only to the extent that those profits are attributable to the company's UK permanent establishment (section 5(3) and 19, Corporation Tax Act 2009). (However, there are exceptions to this general rule - see Basis of taxation: the implications of UK residence and permanent establishments for further detail.)").

${ }^{24}$ Adam H. Rosenzweig, Harnessing the Costs of International Tax Arbitrage, 26 VA. TAX REV. 555,582 (2007); see also Mitchell A. Kane, Strategy and Cooperation in National Responses to International Tax Arbitrage, 53 EMORY L.J. 89, 99 (2004) ("A definition of arbitrage tied to degrees of difference across laws will not be able to filter rate differentials. It is not clear, for example, what it would mean to say that a difference in rates is less of a difference than the difference between, say, rules for determining corporate residency, the latter of which drives the classic international tax arbitrage transaction involving dual resident companies."); cf. Id. at 169 n.23 ("There is one exception. From a revenue standpoint, the economic effect of a variance in rules making up the tax base could always be recast in terms of uniform bases with differing tax rates. Once all differences are viewed as rate differentials it would be possible to ordinalize them. I reject such an approach, though, because it would never be able to filter rate differentials from the class of arbitrage transactions."); Stephen Utz, Ability to Pay, 23 WHITTIER L. 


\section{WHY INCORPORATION IS A BETTER SOLUTION}

This Article's main concern is whether a uniformly adopted system of determining residency would be better solved through uniform adoption of central management and control or through incorporation. ${ }^{25}$ This is not necessarily calling for a reordering of already existing rules into new rules, but a suggestion of picking one for uniformity. ${ }^{26}$ Indeed, it is a perplexing and interesting enigma why the economic operations of a corporation do not mimic the legal structure of multinationals.

The author of this current Article has formerly argued that "[c]entral management and control is the best test for determining corporate residency because it is the test most likely to

REV. 867, 901 (2002) ("Bavaria adopted separate income and capital taxes in 1848, combining them into a single general income tax in 1850. Hesse and the independent republic-city of Bremen also introduced income taxes in 1848. Of these, only the Bremen tax worked well enough to survive for a reasonable period without revision. Inadequate audit machinery is usually blamed for the failure of the Bavarian and Hessian income taxes. Several Prussian governments tinkered with the class and consumption taxes, with a view to making them resemble an income tax more closely. But these experiments fought shy of adopting a workable administrative structure. More theorists joined the income tax movement, however.").

${ }^{25}$ There are many examples of the attempt to establish uniform laws. See, e.g., Edward L. Rubin, The Practice and Discourse of Legal Scholarship, 86 MicH. L. REV. 1835, 1888 n.140 (1988) (citations omitted) ("One example is the standard legal scholarship dealing with payments law, a branch of commercial law. In the 1940s, the American Law Institute, under the direction of Karl Llewellyn, began a comprehensive codification of commercial law, including a revision of the uniform law regarding negotiable instruments. No commentary on this project appeared until the late 1940s, when a few student notes and a few articles by the drafters were published. Extensive critical commentary did not begin until the statute had been promulgated. Similarly, there was very little discussion of electronic funds transfers by academics until legislative efforts were initiated in 1974. Once that occurred, there was a virtual explosion of academic interest, but most of this came too late to affect the legislative effort.").

${ }^{26}$ See generally Marco Jimenez, Distributive Justice and Contract Law: A Hohfeldian Analysis, 43 FLA. ST. U. L. REV. 1265, 1301 n.133 (2016) ("The idea is similar to that first espoused by the Greek philosopher Empedocles, who maintained that everything that exists is but a recombination of that which has come before; nothing is created ex nihilo, for out of nothing comes nothing. See, e.g., FREDERICK COPLESTON, A HISTORY OF PHILOSOPHY 62 (1946) (arguing that, according to Empedocles, 'objects come into being through the mingling of the elements, and they cease to be through the separation of the elements: but the elements themselves neither come into being nor pass away, but remain ever unchanged')"). Cf. J. Christopher Rideout, Penumbral Thinking Revisited: Metaphor in Legal Argumentation, 7 J. Ass'N LEGAL Writing DiRECTORS 155, 159 (2010) ("Like many of the terms used in classical Greek rhetoric, the word 'metaphor' is itself a metaphor, taken from the Greek verb 'metapherein,' meaning 'to transfer.' The transference involves giving one thing a name that belongs to something else. Empedocles, a 5th century B.C. philosopher and orator who taught the noted rhetorician Gorgias, may have been the first to become known for his conscious, deliberate use of metaphor. Aristotle took note of this usage, additional commenting that Empedocles was the first to discover rhetoric. Argumentative use of metaphors goes back a long way."); Allen v. Scholastic Inc., 739 F. Supp. 2d 642, 663 n.154 (S.D.N.Y. 2011) ("To name some examples: according to Greek mythology, Hercules had to accomplish twelve feats in order to expiate the sin of killing his children and to be granted immortality; in Puccini's opera, Turandot, the main character has to solve three riddles to win the hand of a princess or forego his life; and in Mozart's Magic Flute, the lead figure is required to pass several tests in order to enter the Temple of Wisdom and win the hand of his beloved, although he manages to win her despite failing the tests."). 
accurately reflect economic reality of a corporate entity." 27 The author has since become convinced that incorporation is the better solution for determining corporate residency for tax purposes, for two reasons: (1) incorporation - if adopted uniformly - would reflect economic reality more accurately; and (2) incorporation - if adopted uniformly - would allow substance and form to be more uniform, thereby providing for less reliance on substance-over-form arguments, because ultimately form and substance should be united. Indeed, there does not seem to be a clear answer for any of the proposed solutions even though the problem has existed for several decades: "[i]n coping with this and related problems, courts have enunciated a variety of doctrines, such as steptransaction, business-purpose, and substance-over-form. Although the various doctrines overlap and it is not always clear in a particular case which one is most appropriate, their common premise is that the substantive realities of a transaction determine its tax consequences." 28

Courts have long recognized that "[t]he fundamental premise underlying the Internal Revenue Code is that taxation is based upon a transaction's substance rather than its form. Thus sham transactions are not recognized for tax purposes, and losses allegedly generated by such transactions are not deductible." ${ }^{29}$ Moreover, there are multiple types of substance-over-formdoctrine interpretations that courts employ in order to resolve questions of sham transactions, "which include, in relevant part, (1) the conduit theory; (2) the step transaction doctrine, and (3) the economic substance doctrine" ${ }^{30}$ Furthermore, this can become an estimably complex scenario when and where multiple steps are involved in transactions because "the separate steps of a complex transaction should be treated as having independent significance or as related steps in a unified transaction." 31

Courts have often tried to resolve what solution is the best with differing results over time. Many cases agree that "Gregory v. Helvering finds expression in the rule calling for a realistic approach to tax situations. As so broad and unchallenged a principle furnishes only a general direction, it is of little value in the solution of tax problems." ${ }^{32}$ However, analogously, "[t]he substance[-]over[-] form analysis ... is a distinct and limited exception to the general rule under Moline Properties that separate entities must be respected as such for tax purposes." ${ }^{33}$ Thus, there does not seem to be a solid solution to the substance-over-form doctrine. And, by extension, if an agreed-upon substance-over-form doctrine does not exist, then likewise, an agreed-upon test for corporate residency would not exist.

If every country uniformly used the incorporation test for residency, then corporations would no longer face tax incentives to incorporate in a country other than that in which their

${ }^{27}$ Charles Edward Andrew Lincoln IV, Is Incorporation Really Better Than Central Management and Control for Testing Corporate Residency? An Answer to Corporate Tax Evasion and Inversion, 43 OHIO N.U. L. REV. 359, 359 (2017).

${ }^{28}$ King Enters., Inc. v. United States, 418 F.2d 511, 516 n.6 (Ct. Cl. 1969).

${ }^{29}$ Freytag v. Comm'r, 904 F.2d 1011, 1015 (5th Cir. 1990), aff'd, 501 U.S. 868 (1991).

${ }^{30}$ Enbridge Energy Co. v. United States, 553 F. Supp. 2d 716, 726 (S.D. Tex. 2008), aff'd, 354 F. App'x 15 (5th Cir. 2009).

${ }^{31}$ Aeroquip-Vickers, Inc. v. Comm'r, 347 F.3d 173, 182 (6th Cir. 2003). 1989).

${ }^{32}$ Higgins v. Smith, 308 U.S. 473, 476 (1940); see also Humana Inc. v. Comm'r, 881 F.2d 247, 254 (6th Cir.

${ }^{33}$ Humana Inc., 881 F.2d at 254. 
economic activities are concentrated. ${ }^{34}$ Thus, the uniform adoption of the incorporation test for residency would have two beneficial effects. First, incorporation would then more closely reflect economic reality, due to the removal of tax incentives that presently cause incorporation decisions to differ from economic reality or substance. This would eliminate the need to test for residency using the complex and ambiguous central-management-and-control test (which presumes that incorporation often occurs elsewhere than the country where a corporation's economic activities are centered, and determines residency on the basis of the latter). Second, the uniform adoption of the incorporation test for residency - by removing incentives to base incorporation decisions on taxes rather than on economic substance-would eliminate the present complexity of distinguishing between the form and substance of incorporation transactions. Their form and substance would be united, with respect to residency. Transparency, in other words, would be achieved. ${ }^{35}$

Per the second prong, if incorporation is adopted uniformly, it would allow substance and form to be more uniform, thereby providing for less reliance on substance-over-form arguments, because ultimately form and substance should be unified. Courts frequently make similar inquiries. ${ }^{36}$ Such considerations are often made in whether deductions taken were appropriate in tax cases. ${ }^{37}$ However, this idea of using incorporation falls in line squarely with the economic concept of accretion of wealth as indicated by the Haig-Simons definition of income and through Musgravian ${ }^{38}$ economic analysis; even the Tax Court stated, "[g]enuine income represents economic gain, whether calculated under the Haig-Simons definition, . . . or as expansively adumbrated by the Supreme Court in Commissioner v. Glenshaw Glass Co., 348 U.S. 426, 429431 (1955)." ${ }^{39}$ The Court went on to state that "it is the lack of economic reality in the partnerships'

${ }^{34}$ Gator.com Corp. v. L.L. Bean, Inc., 341 F.3d 1072, 1077 (9th Cir. 2003) ("See Perkins v. Benguet Consol. Mining Co., 342 U.S. 437, 72 S.Ct. 413, 96 L.Ed. 485 (1952) (finding general jurisdiction when president of Phillipines-based corporation maintained office, kept company files, held director meetings, distributed salaries, and conducted other company business in the forum state)").

${ }^{35}$ Cf. Fischer Bros. Aviation, Inc. v. Comm'r, 30 T.C.M. (CCH) 1351, 1354 (T.C. 1971) (“The sole disputed question herein is whether certain notes issued at the time of incorporation of petitioners reflect bona fide indebtedness, thereby entitling petitioners to interest deductions under section 163 . The decided cases look to the economic reality of the underlying transaction and often adopt a variety of tests and criteria in resolving this issue.").

${ }^{36}$ As the United States Tax Court stated, "We must first determine whether the incorporation of Dispersalloy was an event with independent economic substance. Respondent does not contend that the incorporation of Dispersalloy was a sham; rather, respondent argues that the incorporation lacked economic substance independent from the later exchange of stock. Respondent urges us to find that the incorporation of Dispersalloy was simply one link in a chain of steps to transfer the assets of petitioners' sole proprietorship to J\&J for stock." Weikel v. Comm'r, 51 T.C.M. (CCH) 432, 439 (T.C. 1986).

${ }^{37}$ The Tax Court dealt with this in Singal v. Commissioner, stating, "[ $\left.\mathrm{t}\right]$ his Court considered the applicability of section 165(c)(2) in Seed v. Commissioner, 52 T.C. 880 (1969). In Seed, the taxpayer, an attorney, was allowed to deduct expenses incurred during an unsuccessful attempt to secure a charter to operate a savings and loan association. This Court found that the taxpayer's activities in the venture qualified as a 'transaction entered into for profit.' These activities included: (1) hiring a law firm and a certified public accountant; (2) hiring a firm to conduct an economic survey of the area; (3) naming the board of directors; (4) authorizing and issuing shares of stock; (5) preparing articles of incorporation; and (6) appearing as a witness at public hearings." Singal v. Comm'r, 44 T.C.M. (CCH) 1521, 1523-24 (T.C. 1982).

${ }^{38}$ Author has not found reference to this word in its adjective form but thinks such a form should exist.

${ }^{39}$ Bealor v. Comm'r, 72 T.C.M. (CCH) 730, 772 (T.C. 1996). 
reported income that explains and justifies respondent's willingness to concede that such income should be reduced to zero in the years affected." 40

\section{MUSGRAVE’s ECONOMIC ANALYSIS IN RELATION TO CAPITAL EXPORT AND CAPITAL IMPORT NEUTRALITY}

Capital export neutrality and capital import neutrality are two of the fundamental theories of structuring an international tax system. ${ }^{41}$ The theory of capital export neutrality would be most easily achieved if "all countries taxed only the worldwide income of their own residents and refrained from taxing income earned within their borders by nonresidents." 42 Capital import neutrality, on the other hand, would be most easily achieved if "all countries taxed all income earned within their borders, did not subject nonresidents to discriminatory rates, and gave up their right to tax foreign source income earned by their own residents." 43

However, it must be clarified what Peggy Musgrave thought was economic accretion of wealth. It should be noted that "normative content can only be derived from economic or philosophical (justice) theories." 44 This is ultimately to say "that four primary norms support accretion taxation: reducing disparities in wealth (a fairness norm), taxing intangible benefits from holding wealth (a fairness norm), conforming to the Haig-Simons ideal income tax base (a fairness and efficiency norm), and structuring a 'neutral' tax system that does not favor one type of investment over another (an efficiency norm)." 45

${ }^{40} I d$.

41 "The general policy framework is a reaffirmation of the principles of residence basis taxation, the economic theory of capital export neutrality, and the link of those principles to the principles of vertical and horizontal tax equity." Stanley I. Langbein, The Future of Capital Export Neutrality: A Comment on Robert Peroni's Path to Progressive Reform of the U.S. International Tax Rules, 51 U. MiAMI L. REV. 1019 (1997).

${ }^{42}$ David L. Forst, The U.S. International Tax Treatment of Partnerships: A Policy-Based Approach, 14 BERKELEY J. INT'L L. 239, 242 (1996).

${ }^{43} I d$. at 247.

${ }^{44}$ Linda M. Beale, Book-Tax Conformity and the Corporate Tax Shelter Debate: Assessing the Proposed Section 475 Mark-to-Market Safe Harbor, 24 VA. TAX REV. 301, 360 n.158 (2004).

${ }^{45}$ For a more complete discussion see id. ("An in-depth discussion of these issues is available in the dialogue between Louis Kaplow and Richard A. Musgrave on horizontal and vertical equity, as well as in more contemporary commentary on the need for an external moral anchor for understanding tax fairness. See, e.g., Richard A. Musgrave, In Defense of an Income Concept, 81 Harv. L. Rev. 44 (Nov. 1967) (arguing that horizontal and vertical equity are aspects of a single fairness measure); Louis Kaplow, Horizontal Equity: Measures in Search of a Principle, 42 Nat'l Tax J. 139 (1989) (arguing that vertical equity is the appropriate fairness measure because focus on horizontal equity merely preserves the status quo); Richard A. Musgrave, Horizontal Equity, Once More, 43 Nat'l Tax J. 113 (1990) (reconsidering his conclusion that horizontal equity is derivative of vertical equity); Louis Kaplow, A Note on Horizontal Equity, 1 Fla. Tax Rev. 191 (1992) (disputing the independent importance of horizontal equity); Richard A. Musgrave, Horizontal Equity: A Further Note, 1 Fla. Tax Rev. 354 (1993) (restating the case for horizontal equity); Paul R. McDaniel \& James R. Repetti, Horizontal and Vertical Equity: The Musgrave/Kaplow Exchange, 1 Fla. Tax Rev. 607 (1993) (concluding that normative content can only be derived from economic or philosophical (justice) theories); Strnad, supra note 157 (suggesting that four primary norms support accretion taxation: reducing disparities in wealth (a fairness norm), taxing intangible benefits from holding wealth (a fairness norm), conforming to the Haig-Simons ideal income tax base (a fairness and efficiency norm), and structuring a 'neutral' tax system that does not favor one type of investment over another (an efficiency norm)"). Cf. 
Indeed, much of the "economics literature since has been greatly influenced by [Musgrave's] work. Musgrave examined only outbound investment from both a theoretical and empirical perspective and concluded that following a policy of capital export neutrality would maximize worldwide welfare." 46 Indeed, "[s] he also concluded that a policy of allowing only a deduction for foreign income taxes, which she labeled 'national neutrality,' would maximize the national welfare of the capital-exporting nation." ${ }^{47}$ In essence, it must be noted that:

Musgrave's analysis was quite straightforward. From a worldwide perspective, she asked what international income tax policies of capital-exporting nations would maximize the sum of domestic and foreign returns on investments and domestic and foreign taxes - the sum of pretax returns - without regard to where in the world returns occur or taxes are collected." 48

This led her to the conclusion that "[f]rom the perspective of worldwide economic efficiency, the best policy is one that has as few efficiency costs as possible. A tax provision is regarded as inefficient whenever the worldwide allocation of investment capital - its location-is different than it would be in the absence of taxes." 49 Avoiding locational distortions of investment therefore is regarded as the most efficient policy." 50

Musgrave's theory is not always all-inclusively fulfilling because "Musgrave's analysis suffers from the general difficulty of using a world without taxes as a baseline since a market economy simply cannot function in the absence of government institutions, which must be financed through taxation." "Ultimately, "in this instance, investors seeking the highest after-tax rates of return will locate investments where the pretax rates of returns are highest if all investment income is taxed identically. Of course, variations in tax rates on investment income among countries are commonplace." 52 And this is a fair concern, but it must be taken in comparison with the idea that "the foundation of Musgrave's theory is an assumption that the home of the taxpayer who owns the income-producing capital has at least a residual interest in all of its taxpayer's income." $" 53$

However, it seems fair that the concepts of tax equity and the best capital export neutrality and capital import neutrality can be aligned with the concepts of incorporation. ${ }^{54}$ This argument in

Peggy Musgrave, United States Taxation of Foreign Investment Income: Issues and Arguments, Cambridge, MA: International Tax Program, Harvard Law School (1969).

${ }^{46}$ Michael J. Graetz, Taxing International Income: Inadequate Principles, Outdated Concepts, and Unsatisfactory Policies, 26 BROOK. J. INT'L L. 1357, 1380 (2001).

${ }^{47} I d$.

${ }^{48}$ Id. at 1380-81; see generally Peggy Musgrave, Taxation of Foreign Investment Income: An Economic Analysis, in Tax Policy in the Global Economy: Selected Essays of Peggy B. Musgrave, (Elgar ed., 2002).

${ }^{49} \mathrm{Id}$. at 1381.

${ }^{50} \mathrm{Id}$.

${ }^{51}$ Id. at 1381 n.82.

${ }^{52} I d$.

${ }^{53}$ Nancy H. Kaufman, Fairness and the Taxation of International Income, 29 LAW \& POL'Y INT'L BUS. 145,198 (1998).

${ }^{54}$ See Michael S. Knoll, Reconsidering International Tax Neutrality, 64 TAx L. REV. 99, 99-100 (2011) 
connection with Musgrave is only as strong as the connection that Musgrave noted "that horizontal equity depends on 'an objective index of equality or inequality' for its incorporation into a particular tax system. $" 55$

Thus, the reason incorporation is likely a better solution than central management and control is because it will help improve capital export neutrality and capital import neutrality. ${ }^{56}$ Moreover, Musgrave's theory of economic increase in wealth in relation to taxation supports this concept that incorporation is a better solution.

\section{Further Thoughts: Distinction BetweEn a Legal Formalistic And Legal REAListic PERSPECTIVE ON CORPORATE TAX RESIDENCY}

As a corollary to the purely legal and economic perspective dénouement, the distinction between central management and control and incorporation highlights a fundamental theoretical distinction in domestic tax law and international tax law. The central-management-and-control test prescribes a greater value on a legal realistic perspective on corporate tax residency. The incorporation test places a value on the legal formalistic perspective on corporate tax residency. Ultimately, this is a distinction between placing more value on the jurisprudential values of legal formalism and legal realism.

It has been stated that there are "two foundational theories of judicial decision making: legal formalism and legal realism. Every other description of judicial adjudication is an offshoot of one - or, on occasion, both - of these theories. Originalism and purposivism, eclecticism and interpretivism, even pragmatism and critical legal studies: all trace their lineage back to legal formalism or legal realism. $" 57$

However, in law schools in the United States, "[g]iven the centrality of these two theories to academic discourse, it is only natural that legal formalism and legal realism are also at the core of public debate on judicial decision making." ${ }^{8}$ Furthermore, "[w] hat is alarming, however, is the stark contrast between the way these theories are presented in popular culture and the way they are discussed in the private, or academic, domain." 59 In contrast, "[i]n public, legal formalism and legal realism are depicted in extreme, simplified terms that barely resemble the nuanced treatment

("Using CEN and CIN as defined by Musgrave, Shaheen argues that a territorial tax system can simultaneously satisfy both neutrality benchmarks without the need for governments to harmonize tax rates"); $c f$. Fadi Shaheen, International Tax Neutrality: Revisited, 64 TAx L. REV. 131, 131 (2011) ("Since Peggy Musgrave's 1963 and 1969 work, CEN and CIN, and more recently CON and NON, have been the subject of extensive discussions in the tax policy literature by economists and lawyers.").

55 John A. Miller, Equal Taxation: A Commentary, 29 HofsTRA L. REv. 529, 535 n.46 (2000) (citations omitted).

${ }^{56}$ Cf. Robert J. Peroni, Deferral of U.S. Tax on International Income: End It, Don't Mend It—Why Should We Be Stuck in the Middle with Subpart F?, 79 TEX. L. REV. 1609 (2001).

${ }^{57}$ Jason Iuliano, The Supreme Court's Noble Lie, 51 U.C. DAVIS L. REv. 911, 919 (2018). For a well-structured critique against the proposition that legal formalism and legal realism are the basis of judicial decision making, see John M. Breen \& Lee J. Strang, The Forgotten Jurisprudential Debate: Catholic Legal Thought's Response to Legal Realism, 98 MARQUETTE L.R. 1203 (2015).

${ }^{58} I d$.

${ }^{59} I d$. 
they receive in legal scholarship. The differences, in fact, are so vast that they are more easily thought of as distinct theories necessitating distinct labels." 60

There exists "some degree of formalism in every legal system. Rules are established and generally followed. American legal realism, in rejecting legal formalism, relegated legal rules to a relatively minor place in its descriptive analysis of law and legal systems. Realists ultimately expanded the legal landscape beyond the activities of courts to include all that happens in a legal system." ${ }^{61}$ Historically, "Realists started by essentially deconstructing judicial decisionsdemonstrating that decisions were often based on internal contradictions and false precedents. The presence of 'rules' - in the form of statutes or precedents - does not result in predictability; rather, legal decisions were inherently uncertain and unpredictable." 62

Compared to the United Kingdom, "American judicial reasoning is commonly believed to have internalized the lessons of Legal Realism, whereas English judicial thinking is taken to represent the vestiges of Legal Formalism." 63 This is a vital distinction given that both systems essentially originated together in England, because, while "judges in both legal systems arrive at more or less similar solutions to the problems that they identify, their 'styles of decisionmaking are strikingly different.' American (i.e., Delaware) judges appear to tackle the policy and economic issues at stake directly as part of their reasoning, whereas English judges do so from within the language of case law and the traditional sources of legal reasoning." 64 Although it is unclear "whether the difference actually affects outcomes in cases ... one of the effects of Legal Realism on reasoning in this domain may have been its relaxation of the stylistic (or formal) constraints of legal doctrine, which has enabled lawyers and judges to focus more directly on the normative considerations at stake." 65

Overall, the distinction between the two vital theories of corporate residency-central management and control and incorporation - ultimately highlights a fundamental distinction in domestic tax law and international tax law. They fit squarely into the conceptions of legal formalism and legal realism.

However, although incorporation would prescribe a more formalistic approach, this Article has attempted to argue that the economic reality inherent in a unified and uniform approach to incorporation could lead to an equally appealing decision from a legal realism prism of interpreting international tax law. This is because legal formalism focuses on normative theories of law-a system of incorporation would be based on purely theoretical, already established systems of legal principles. As a consequence, incorporation is based on purely legal and previously decided principles of law. Alternatively, legal realism is often cited to be the opposite of legal formalism in some sense. ${ }^{6}$ However, in this case, if jurisdictions adopted uniform approaches, legal

${ }^{60}$ Id. at $919-20$.

${ }^{61}$ Michael P. Ambrosio, Legal Realism, N.J. LAw., Oct. 2000, at 30.

62 Joseph A. Reinert, The Myth of Judicial Activism, VT. B.J., Winter 2003-2004, at 35.

${ }^{63}$ Shyamkrishna Balganesh, The Constraint of Legal Doctrine, 163 U. PA. L. REV. 1843, 1855 (2015).

${ }^{64} I d$.

${ }^{65} \mathrm{Id}$. at $1855-56$.

66 “L.L. Fuller, American Legal Realism, 82 U. PA. L. REV. 429, 436-37 (1934) (explaining that traditional judicial philosophy based on formalism and restraint grounds decisions in the mechanical and technical application of the law due to a belief that such techniques created greater predictability, but arguing that such an approach in fact did the opposite because it ignored the subjective factors that inevitably influence every judge and judicial 
principles would be the naturalistic approach to law. In this sense, legal realism and legal formalism would be unified and merged.

\section{CONCLUSION}

In conclusion, this Article argued that incorporation - if adopted uniformly-would (1) reflect economic reality more accurately; and (2) enable uniform substance and form, thereby decreasing reliance on substance-over-form arguments, because ultimately form and substance should be united. Moreover, the conception of unified incorporation as a test for corporate residency in an international context does not solely lie in the sense of legal formalism, but also, in time, could lend itself to economic legal realism.

decision)." Katherine H. Blankenship, The Great Tactician: The Chief Justice, Obamacare, and Walking the Tightrope of Partisan Politics, 2 Belmont L. Rev. 149, 184 n.5 (2015); see Joseph H. Sommer, Where Is a Bank Account?, 57 MD. L. REV. 1, 60-61 (1998); cf. Joseph William Singer, Legal Realism Now, 76 CAL. L. REV. 465, 477-82 (1988). 